\title{
POPULAR PREJUDICE AND CONSTITUTIONAL AMENDATORY CONVENTIONS.
}

By John A. Hoober, LL.B., Yale Law School.

What is there in the history, power, or mode of procedure of constitutional conventions which should deservedly make them contend against unpopularity? Have they in times past met in response to arbitrary calls, invested with powers of annihilation to the state; have they acted unofficially, disregarding law and custom, supplanting existing organization through revolutionary methods; or have they when charged with definite powers disregarded the purposes of assembling, seemingly acting as if they were above the law and its limitations and violating state interests to promote selfish ends? If such facts mark their genesis and development no plea can be interposed in their behaif. But their history, from the earliest original to the latest amendatory convention, warrants no such conclusion.

Let us consider the cause of and foundation for the widespread prejudice that plainly exists, taking as a case the experience of a neighboring state within the past several months where a convention in all its phases received a full discussion. A defect or inadequacy had manifested itself in the constitution; forces were at work undermining well-regulated liberty. Some of the citizens, recognizing that weak fundamental law commanded neither fear nor respect and that unless the constitution would be amended state and individual interests would feel the pressure of such defects, appealed for a clearer constitutional statement of their rights. To the people the legislature entrusted the ministerial duty of voting for or against the convention. The vote showed an overwhelming opposition to the movement. A study of- the press articles during the campaign seems to admit of an analysis of the more vigorous protests in the following divisions:

I. From those in favor of entrusting the work to.the legislature and not to a special commission. 
2. From those who oppose any change at any time and in any manner of the organic law of the state.

3. Those who fear that a convention once assembled can disregard all limitations imposed upon it and take to itself an absolute sovereignty, freed from the responsibility even of submitting its work to the people for ratification or disapproval.

As to the first objection. A legislature is not adapted to work of this character and the impropriety of working on a line for which there is no qualification is inferrible from the fact that no one of ordinary prudence would follow such a principle. "An assembly that solves problems of municipal law is not tensioned for working out principles of fundamental law." The latter requires a higher grade of talents, a wider experience in the affairs of the state, a truer sense of the expediency of recognizing social movements, a keener discernment of the reciprocity of right and obligation, and a profounder study of state necessities than the former. The legislature through the complexity of the work brought before it is forced to hasty legislation at once incompatible with the exactness required in framing organic law. As the close of the session draws near the press and rush renders incapable of effective work even those whose integrity of purpose may be unquestioned. Party interests must be subserved and the party influence presses most forcibly until the purposes desired are secured. The slowness of the earlier part of the session is a resultant in part of the variant nature of the business and in part of the policy required to attain ends. The admixture of interests represented in its members will not admit of that freedom of action required where all else but the one work in hand is relegated to the rear, as is necessary for effective work in a constitutional convention. This multiplicity of interests and complexity of business will not admit of that concerted, inter-dependent action which the supreme importance of the work of a convention demands. At work to-day on a trivial private bill and to-morrow on a vital question of fundamental law - the transition is too great for the mind of the average legislator. The method of a legislature, moreover, is ill adapted to the work of amendment. The cumbrous system of a myriad of committees fails to set free an interchange of opinion on the floor of the assembly, in which place alone the technical refinement and legal astuteness of the lawyer and jurist meet the views of the man of hard, practical wisdom. No legislative body having an elaborate system of committees can furnish the directness of action required of a constitutional convention. A legislature has, moreover, an inherent 
weakness in the two-house plan. Shuffling a measure back and forth from house to house, shirking responsibility by this evasion, running away by insensible degrees from the point in issue, and finally killing the measure without giving the people an opportunity to fix the responsibility - violative of the trust imposed in them-that is no fit place for vital action where the habit of obedience to the constituency has not been acquired. A convention, on the contrary, avoids all these legislative drawbacks. The delegates are selected for one determinate purpose ensuring a concentration of energies; that pot-pourri of motives which sends many unworthy representatives to legislatures, and which the purely unselfish members are powerless to countervail, is found lacking where only men capable of high trusts are sent. Commissioned to search out defects they are watchful for any opening which admits of a violation and are energetic to secure the remedy. Their oneness of purpose means a unity of action, ensuring expedition; and their clear intelligence makes the act of changing an act of purifying.

As to the second class - those who in their antiquated conservatism so worship the letter of the constitution as to regard any change an impairment of its virtues. To such, new-modelling a constitution is a work prompted by an unreliable public feeling. Undoubtedly, there is in a republic an inborn regard and reverence for the written organic law of the land-a bulwark to republican institutions which minimizes the chance of radical and revolutionary ideas from taking root-but in every government a wrong tolerated crowds out a right and an error known to exist in the fundamental law requires correction. No matter how strong may be the restrictive policy of the people regarding "Constitution patching" it is their duty to re-cast their fundamental law when defects are apparent therein.

Many of our state constitutions were framed when haste was necessary and when permanency was not in the framers' minds. But under the pressure of this feeling they have been endured until now when their inadequacy is manifest. Constitutional principles are better understood now than at the time of framing, and the absence of essential provisions through accident or inadvertence possibly, but more probably through a lack of knowledge in the framers, prevents the constitution from harmonizing with the social and economic conditions of the day, and fails to apprise the people of their rights and obligations. The movements of organized labor, the question of taxation, these and others have made changes, but they have not been added to the fundamental laws 
-a defect which strains the state frame-work and weakens it. Such a political condition invites disorder, and progress in a State is co-extensive and co-existent with peace-civil polity, therefore, requires that they be kept in close companionship.

How then are these difficulties to be met? By yielding to the temptation to violate a constitutional provision which conflicts with state interests or under the pressure of state necessity to disregard it ? Will civic dignity allow a reasonable interpretation of a provision to be narrowed in order to save the constitution from amendment which the views of some hold to be a vice? Or shall we through the propulsive energy of public opinion and public necessity brought to bear on the judiciary force it to practically give the desired amendatory enactments? Or shall we recognize the transcendental claims for the dignity of the constitution which this class urges and remain remediless? Such plans are unworthy of reasoning men. A defect always works evil, and strong public policy demands a correction. Our regard for the constitution was a part of our heritage, but this will not justify us in tolerating that which will not reconcile progress with safety. A constitution in its nature can deal only in generalities, yet there is no reason why these should be clonded mysteries to the citizens - consonance with the principles of government no more requires obscurity than it does any other vice. A constitution should not be inflexible, withal, for defined powers made determinate while the state is in a period of transition soon show their weaknessan inseparable consequent of an attempt to make sharp the line of cleavage between the permissible and the forbidden during a period of growth or decay.

If such unsatisfactoriness results, can I, a unit of the state, "sitting in my arbor by the wayside, smoking my hookah of contentment and eating the sweet lotus leaves of indolence," justify myself in my unconcern because the constitution is avowedly good in aim and purpose, because its framers had the best intentions? Would private right or state necessity justify me in a course so incompatible with the healthy life of the state? Is not my coquetting with my privilege and obligation as a citizen antirepublican? Does not my unreasonable nicety on the question of constitutional amendments make me powerless to bear my proportionate share of duties as a member of the state society? Is there a forum of mind or morality which recognizing the peculiar institutions of a republic would require of me as a follower such self sacrifice for the good of the state? It is my duty to demand my rights. "No truth is becoming more clear in our day than 
that in demanding everywhere the supreme direction of the Commonwealth and in asserting a right to determine the modes and instruments of its administration, the people-the zation-are but re-claiming their own."

The third class of objectors bring forward the legal aspect of the question in asking : Can a convention once assembled impute to itself sovereignty? The question has suggested itself to honest minds. Can we be reasonably certain that the powers we, as electors delegate to the convention, will be honestly executed ? If we commission them with a determinate function can they gather to themselves greater attributions of power? Can they supplant our wishes, treading under foot public policy and private right? Must we accept the fruit of violated instructions? Can they change our express mandate and make it of no obligatory force? Let us consider.

A convention can have entrusted to it express and implied powers. The general rule as to implied powers (Jameson on Constitutional Conventions, page 455) is that they are such as "are requisite to secure their own comfort, to protect and preserve their dignity and efficiency, and to ensure orderly procedure in their business." This line of powers, it is evident, would not admit of a convention taking to itself any force capable of injuring any state, governmen: al or individual interests, and should it be attempted the streng:ts of the judiciary would speedily make nugatory any such ill-timed scheme. Express powers, then, only demand our consideration. If the convention obeys instructions as mapped out by the people it completes its work and suffers dissolution by that act. But it disregards the limitations imposed upon it. Were, therefore, (I) these restrictions mandatory or discretionary, and (2) can the people be the final arbiters making the convention's work merely recommendatory or is it binding upon them without submission for their inspection. The first of these two questions received a thorough consideration in the case of Wood's Appeal, ${ }_{75} \mathrm{~Pa}$. State Reports, page 7x, wherein Judge Agnew held:

"A Convention has no inherent rights : it exercises powers only. Delegated power defines itself. To be delegated it must come in some adopted manner to convey it by some defined means. This adopted manner, therefore, becomes the measure of the power confined. The right of the people is absolute in the language of the Bill of Rights to.' alter, reform or abolish their government in such manner as they may think proper.' This right being theirs they may impart so much or so little of it as they shall deem expedient. * * * To impute absolute power to a convention of mere delegates * * * is to assume a grant by the people without terms, without the 
means of limitation, and without any clearly evinced intent. It is an assumption without a just basis against the security, the interest and the welfare of the people which no body of men have a right to make and no judicial reason or rule can justify."

And again :

"The people have the same right to limit the power of their delegates that they have to bind the power of their representatives. Each are representatives but only in a different sphere. $\quad * * *$ The right of the people to restrain their delegates by law cannot be denied unless the power to call a convention by law and the right of self-protection be also denied."

The view of the jurist as above given is acquiesced in by Jameson on Constitutional Conventions, page 493, as follows :

"The Act of Assembly under which a convention meets is its charter. * * * What is a convention that it should assume to be exempt from obedience to that department of the government which is charged with higher sovereign attributes -is more nearly sovereign - than any other in it? Does it claim itself to be above the legislature? Let it show its warrant for a claim so exorbitant, for upon it must rest the burden of proving what contradicts all political analogies and the first principles of constitutional government. It cannot find that warrant in the mandate of the power by whose fiat it came into being for by hypothesis that is expressly to the contrary. * * * Nor can a warrant for the claim be found in the principles which preside over the genesis and healthy growth of the communities for those principles require conventions to rank themselves as the servants not the masters of the people; and when the will of the people is known to conform themselves scrupulously to it."

The same view has been taken by a member of a constitutional convention. In the Pennsylvania Convention of r872-73, Jeremiah Black, a delegate, speaking of the binding power of legislative limitations, said :

"No one will deny that we are sitting here in pursuance of certain acts of the legislature - the two acts of the legislature - one which authorized a vote by the people upon the question, and the other one which authorized the election of delegates to the Convention. If we derive our power from that source, is it possible that we can have it without the limitations that were imposed upon it by those who created it? I don't think that question can be answered in but one way." (See Debates Pa. Convention, I872, vol. I, pp. 57, 58).

The second question presents itself. Suppose the convention has apparently limited itself by the restrictions imposed but yet refuses to submit its work to the people for ratification or disapproval can its work go into effect without such ratification? As constituted judges of the work can the people not feel safe in the belief that the work of the convention must be submitted to them? This thought also receives careful consideration in the case cited above (Wood's Appeal, 75 Pa. State Reports, p 74) Judge Agnew holding that: 
"A limit must be set to power. No people can be safe in the presence of a divine right to rule or of self-imputed sovereignty in their servants to bind them without ratification. * * * Let a convention in such seasons possess by mere imputation all the powers of the people, and what security is there for their fundamental rights? * * * Once assembled a convention according to this dogma is all powerful * * and may proclaim a constitution without let or hindrance. The fundamental rights of the people, the true principle of civil liberty, the nature of delegated powers and the liability of the people to a temporary convention all rise up in earnest protest against such a doctrine of imputed sovereignty in mere servants of the people."

No agent or subordinate can claim the powers, or franchises of the people except by express grant or by a plain implication.

Such objections, however, are unworthy of consideration from the fact of their rare occurrence. There have been assembled in the United States nearly two hundred constitutional conventions of different kinds and probably in only three, the Georgia convention of 1789 , the Illinois convention of 1862 , and the Pennsylvania convention of $1872-73$, have any instructions been violated and then only in matters of minor importance. These violations, probably, were prompted by a feeling of the need of the times for the change recommended by the Pennsylvania convention, which was an over-stepping of its powers, was subsequently ratified by the people. (See Debates of Pennsylvania Convention of 1872 , vol. 8, pages $620-712)$.

But the question naturally arises whether there is no weakness in the structure of a modern convention. Familiar as every one interested in the science of government must be, with the theory as well as the workings of all legislative bodies of which a constitutional convention is a type, the question is one not of abstract principles to be solved by a publicist or jurist but one of fact capable of solution by the people. The answer is focussed here - the matter of paramount importance is the selection of suitable delegates, men of sound sense and patriotism, of hard, practical wisdom, upon whom the loose jargon of political organs and the scare arguments of subsidized newspapers fall without making an impression. Those only can be trusted who recognize that social duties and obligations are superior to individual rights and interests and who can be relied on to do naught save what is legally and morally defensible. The likelihood of danger from this source is easy to overcome - let the people act as if they thought the convention required the best efforts of the best men, and the best men will offer themselves for the work; if the people are indifferent and unconcerned they can expect, as in any case will 
happen that the boss-favoring and the corporation-favoring aspirant, throwing away all sense of honor and patriotism to his state and of obligation to his constituency will do his worst for his odious master. But granting the latter possibility for argument's sake would anything be accomplished? Granted that the delegates would turn aside from all considerations of the social needs could they through the bastard power even momentarily accomplish their corrupt object? The people having hedged about the delegated powers with restrictive checks which the courts have adjudged to be mandatory and likewise that their action must be submitted to the people for ratification or rejection it is at once apparent that such a move on the part of the delegates would be futile and ill-fated. Fears of trouble from these sources are groundless. Who would look for an organized party resistance to the expressed wish of the people - such a stand would only antedate the party's ruin. Where the masses make a request who would look for the request suffering a lonely advocacy-questions of living importance which have received the people's attention it is our experience never stand unsupported. The high excellence of a constitutional reform would attract, it can reasonably be supposed, the best men of all parties to its support. Matthew Arnold's " saving remnant," would spring into a material being here to vanquish self-interests and offensive partisanship, sharply drawn as party dissensions may be. Statesmanship will be accorded here one of its few opportunities for assertive, aggressive work and its productivity of good will be more apparent and to a wider range of subjects than many of its triumphs on other fields of struggle.

Possibly no cause for fear can be well grounded concerning the work of political intimidators on the delegates elected by the people. A constitutional convention, mayhaps, does not work directly enough against corporations to draw out from them an opposition; no party will give orders to fly in the face of destiny and decimate its own number; and no delegate will be honored with an election whose integrity of purpose the people are not assured of before the election. This is the recorded experience of past conventions. Policy - individual, party or public, - is forceful and restraining when the expediency of a movement-individual, party, or public - is in question.

But does not the history of constitutional conventions dispel any fear that any but the best men will be selected to sit as delegates. In the Massachusetts convention of 1820 sat Mr. Justice Story and Daniel Webster. Would not the judicial learning of 
the former have swayed his co-laborers into a line of right thinking and right doing had occasion served to exercise his powers, or had the convention attempted to over-step its defined rights would the eloquence of Webster have been nursed in silence? Did Chancellor Kent and the Livingstons in the New York convention of I82 1 fail to consider the peculiar dangers of the age or the almost sacred character of their work ? Could any movement not in consonance with the principles of peaceful and constitutional government have escaped the sleepless vigilance of John Randolph in the Virginia convention of 1829 ? In transacting business of so transcendent importance would Willard Hall in the Delaware convention of 1852 not have prevented anything puerile and unworthy so far as it lay in his power? Did Choate in the Massachusetts convention of $r 853$ lack the prudent foresight and conservatism one would expect to find in a great lawyer? Or did not Jeremiah Black in the Pennsylvania convention of $1872-73$ strive with a vigor and a-steadfast zeal worthy of his noble character to make the work of their assembly a work of conscience as well as of political right?

We read our answer in their names and lives. Every step taken was the culled good of past experience and was made capable in so far as in their power lay of meeting the exigency of their condition. They felt it a favor to be elected to represent a free people and they acted on that feeling. They felt they were bound in morals and in law to a care proportionate to the gravity of the undertaking and they worked on that principle. Men today are constructed on a like principle and will pledge themselves to a like scrupulous exactness. To men fashioned in this mould a power need not be construed in its hard literalism - their political conscience and their known punctilious conformity to whatever is honorable being a satisfying guarantee for their actions. It only requires to attain to this state that the people show their consciousness of their political needs by demanding the necessary amendments. Such an appeal betokens well - at once indicative of a sound political training; of a guarded watch over their rights and an acknowledgment of reciprocal obligations - a true test of citizenship. 